\title{
Ethnic disparities in higher education
}

\author{
Aslan Zorlu
}

Correspondence: A.Zorlu@uva.nl

University of Amsterdam,

Amsterdam, Netherlands

\section{Springer}

\begin{abstract}
Using unique administrative individual data, this paper examines ethnic differences in degree performance in Dutch colleges and universities. The paper estimates parametric duration models and accounts for unobserved heterogeneity to assess the sources of ethnic disparities. The analysis shows that ethnic minorities from nonwestern countries have a significantly lower degree performance and higher risk of dropping-out. Especially, Turkish, Moroccan and Caribbean students are less likely to graduate, and graduates among them need much more time to complete their study. There is no evidence that this disadvantage stems from poor parental socioeconomic position and the choice of study subject.
\end{abstract}

\section{Introduction}

Ethnic disparities in higher education have received little attention in European studies from scholars from any discipline, in contrast to an overall ethnic gap in educational attainment Chiswick and DebBurman, (2004); Van Ours and Veenman, (2003); Nielsen et al., (2003); Riphahn, (2003); Gang and Zimmermann, 2000). Most research has stressed educational achievement of ethnic minorities in lower segments of the education system, especially on the level of secondary school Colding (2006); Colding et al., (2009); Kalmijn and Kraaykamp, (2003). However, there is good reason to assess degree achievement of ethnic minorities in higher education. Recent studies show that ethnic minorities leave the education system relatively early in the Netherlands (Herman et al. 2007). Only a small percentage of young people from ethnic minorities continue their education in colleges and universities, although this percentage is steadily growing. Still, a relatively high portion of ethnic minority students do not finish their course of study compared to Dutch students Bijl et al. (2005).

Although higher education increasingly gains importance, little is known about the performance of ethnic minority students in higher education. The lack of attention is likely related to a small number of students from disadvantaged minority groups in higher education. Correspondingly, survey data used in these studies include a small number of ethnic minority students which is hard to analyze statistically. In the European context, there is little attention to ethnic differences in the degree performance of native and ethnic minority students. In a study on ethnic minorities' achievement in the UK higher education system, (Leslie 2005) attributes the weaker degree results of ethnic minority students to their lower prior-qualifications and the choice of subjects associated with a low probability of degree achievement. In contrast to Europe, educational disparities for racial and ethnic minorities in the United States have received much more

(c) 2013 Zorlu; licensee Springer. This is an Open Access article distributed under the terms of the Creative Commons Attribution License (http://creativecommons.org/licenses/by/2.0), which permits unrestricted use, distribution, and reproduction in any medium, provided the original work is properly cited. 
attention Strayhorn, (2010); Warikoo and Carter, (2009); Arbona and Nora, (2007); Kao and Thompson, (2003).

This paper addresses ethnic disparities in the achievement of students in the Dutch university education (WO) and high vocational education (HBO). Theoretically, the degree performance of ethnic minority students can be either higher or lower than native Dutch students. This will be lower if ethnic minority students face particular difficulties to attend the higher education. Such difficulties can arise from parental socioeconomic disadvantages or from social exclusion by institutions. Parents of ethnic minority students are relatively low-educated, and they have lower earnings and higher unemployment and welfare dependency compared with the native Dutch population Zorlu and Hartog, (2012). Studies on the educational achievement of ethnic minorities have led to a consensus among social scientists that socioeconomic background, often approximated by the education level and income of parents, plays an important role in predicting ethnic and racial disparity in schooling performance Cameron and Heckman, (2001); van Ours and Veenman, (2003); Schnepf, (2007); Herman et al. (2007). Alternatively, the degree performance of ethnic minority students will be higher if ethnic minority students are a selective group of most able students who were successful in overcoming all obstacles in their earlier educational achievements. Such a positive selection can arise when only a small portion of pupils from a large potential pupil population, who are qualified for higher education, tends to go on into higher education. This is more relevant for minority ethnic students from non-western countries, compared to Dutch students who more often continue to attend higher education. If this type of positive selectivity for ethnic minority students is at work, these students will complete their study more likely than Dutch students who face less difficulty in educational upward mobility.

This paper contributes to the literature by examining differences in degree achievement between ethnic minorities and Dutch in the Netherlands higher education. Using unique administrative data of the entire 1996 intake cohort in 2005, we consider effects of the prehigher education qualifications, choice of study track and subject, and parental background. Data include information about the educational career of students who enrolled in a higher education institution in 1996 during 10 years, from 1996 through 2005. We apply parametric duration models to examine degree achievement across the major ethnic groups in the Netherlands. Administrative data provide accurate information about pre-college education, students' formal involvement in the higher education system, their degree achievement within ten years and parental labor market status but data do not include attitudinal variables and a measure of ability that can potentially affect the performance. We deal with this problem by accounting for unobserved individual heterogeneity in data.

The results of this study can be informative for policy makers and scholars. A relatively high achievement of ethnic minority students can be seen as an early indication for social and economic integration while a low performance may be regarded as persistence of ethnic disadvantages. In addition, it is often argued that ethnic minority graduates from most disadvantaged groups would serve as an example for other ethnic minority pupils.

\section{The Dutch education system}

The Dutch higher education system is organized as a binary system (in the German style): higher vocational colleges (HBO; Hogere BeroepsOnderwijs in Dutch; literally 
translated: higher vocational education) and scientific education (WO; Wetenschappelijk Onderwijs in Dutch; literally translated: scientific education), as illustrated by Figure 1. The fundamental difference between these two tracks is the curriculum offered by these institutions, not fields of science: the HBO institutions provide higher professional education in applied sciences, while the WO institutions (universities) conduct scientific research and provide scientific education and academic training. The WO track includes both the social sciences and the humanities.

In the Netherlands, university-level training is provided by fourteen public universities (of which one offers only distance learning), which are publicly funded. There is only one private university which specializes in management courses. In 2000, there were about $55 \mathrm{HBO}$ institutions, of which about $90 \%$, are also publicly funded Rijken et al., (2007). It is important to note that the Dutch higher education system is strongly dominated by publicly funded colleges and universities which is a crucial difference from the US higher education system.

The HBO programs are practically-oriented, not research-oriented. HBO institutions offer a wide range of programs, many of which in other countries are offered by universities, such as teacher training, management programs, journalism etc. In line with the orientation, the entry requirement conditions for access are different for the $\mathrm{HBO}$ and $\mathrm{WO}$ (see Figure 1). Candidates for the WO are required to have a certificate from pre-university education (VWO, Voorbereidend Wetenschappelijk Onderwijs; literally translated: preparatory scientific education) or to have a completed the first year of an HBO program, while the minimum requirement for access to $\mathrm{HBO}$ programs is either a certificate from senior general secondary education (HAVO, Hoger Algemeen Voortgezet Onderwijs; literally translated: higher general continued education) or a level-4 diploma from the senior secondary vocational education program (MBO, Middelbaar BeroepsOnderwijs; literally translated: intermediate vocational education). In addition, higher education institutions can impose supplementary requirements regarding some specific skills and talent, or fitness for profession. Generally, all students with a high school degree have access to higher education.

The Dutch education system was different from the Anglo-Saxon Bachelor-Master type until the 2002/2003 when the higher education system in the Netherlands was organized as Bachelor-Master structure in the framework of the harmonization of

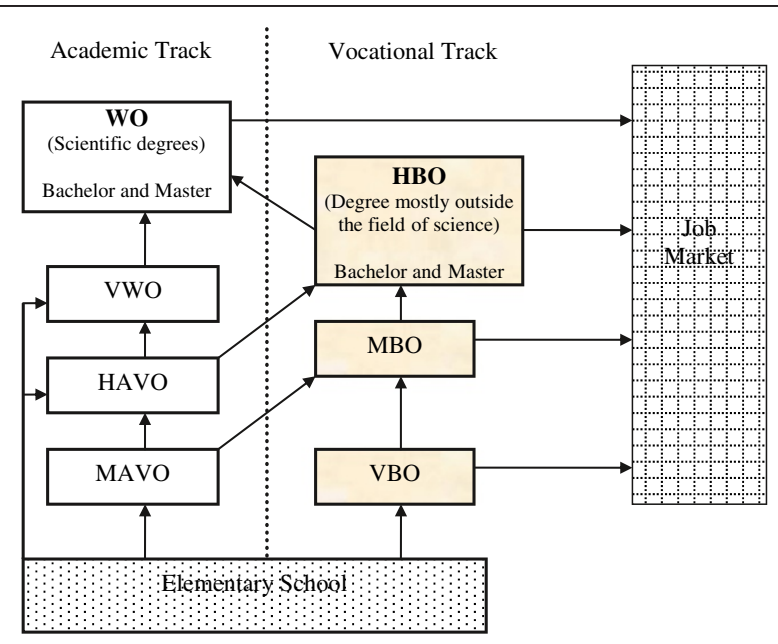

Figure 1 Main flows in the Dutch educational system. 
educational systems in the European Union, regulated by the Bologna agreement (1999). For new entrants since September 2002, the new system has been applied. The most relevant implication of this new system is for WO programs. Universities now offer bachelor programs of three years and master programs of one or two years in the second phase, similar to the American system.

Before this new structure, both study types formally lasted 4 years. Completion of any university degree led to the doctorandus (Drs.) degree which was comparable to a master of science degree (MA) in the United States while HBO students received a different level of degree which was equivalent to a Bachelor degree. Note that Dutch universities did not offer a separate bachelor degree. The educational path through universities led directly to a MA degree. These two tracks are linked in two ways. First, a student satisfying $\mathrm{HBO}$ entry requirements can first complete the first year of a $\mathrm{HBO}$ program and may then switch to a closely related program at a university. Alternatively, students can first complete a HBO-degree and subsequently start with a university program.

Since our data are on the entrants in 1996 only, for this study, the old higher education system applies. It is of particular importance for this investigation that the formal duration of study is 4 years. However, some earlier graduations can not be excluded since any (unobserved) compensation for earlier training can shorten this formal period. Labor market prospects of students following either educational track are often different although there are many overlaps regarding jobs and occupations. University graduates are usually expected to perform more complex and abstract and theoretical tasks while HBO graduates are supposed to perform more executive tasks.

In the Dutch higher education system, the role of income is less pronounced because of the relatively low tuition fees, and the rather generous system of student support. Regular full-time students are eligible for publicly provided student support for the nominal duration of a higher education program. It is also worth noting that quality differences between educational institutions providing similar level of education are likely to be considerably lower in the Netherlands than in the US. Most students choose their educational institutions on the basis of geographical distance and availability of desired subject rather than the academic reputation of the institution.

\section{Ethnic minorities in the Netherlands}

This study decomposes ethnic minority students in the Netherlands higher education into four major groups taking into account parental immigration history and socioeconomic position of these students and their own educational attainment ${ }^{1}$. The first group includes students from Turkish and Moroccan origin (Mediterranean). The second group comprises students from Suriname and the Dutch Antilles, (Caribbean). The third group is an aggregate of students from other non-western countries (ONW) which is a heterogeneous group. The fourth group covers students originating from western countries (Western). The first Turkish and Moroccan immigrants came to the Netherlands as guest workers in the 1960s while immigration flows from Surinam and the Netherlands Antilles have been derived from colonial relations. Immigration from Western countries has been related to economic conditions. The category 'other nonwestern' covers a variety of more recent immigrants from developing countries who frequently entered as asylum seekers or family migrants. 
This historical background reflects the socioeconomic position of these groups and their cultural distance from the host society. Caribbean migrants often speak Dutch and adopt cultural norms similar to those of the Dutch through their colonial relations. Their labor-market position is somewhat less favorable than that of the native Dutch. In contrast, the predominantly Muslim Mediterranean migrants are frequently less well educated, hardly ever speak Dutch prior to immigration, and have a greater cultural distance from the Dutch. There is some empirical evidence that these migrants face significant difficulties in the Dutch education system, labor and housing markets. They have a high drop-out rate in education, they are frequently unemployed and they are concentrated at the bottom of the occupational distribution.

It should be noted that a large portion of ethnic minority students were born in the Netherlands or immigrated at young ages and passed through primary and secondary education in the Netherlands. This implies that these students, different than their parents, have been exposed to mainstream norms and values in the Dutch society. Only a small share of ethnic minority students possibly came for study. Also these students should satisfy standard entry-requirements of higher education, including language. These entry conditions ensure that students will not face basic language problems and they will not lack relevant information. So, any differences in performance of the groups distinguished will reflect ethnic disparity. Such disparities can stem from many sources, such as motivation, ability, wrong choice of study/institution and social class.

\section{Modeling arguments}

In contrast to Europe, racial and ethnic disparities in US higher education have received considerable empirical and theoretical attention. American research has documented a significant achievement gap between less-advantaged groups such as African Americans, Hispanics and native Americans and more advantaged groups such as whites and Asian Americans although this gap has narrowed in general over the last three decades Kao and Thompson (2003). Much of the discussion of minorities' educational achievement follows three main arguments. The first argument credits the structural position of ethnic groups, emphasizing immigration history and the skills immigrants brought with them. The impact of the structural position of an ethnic group is conventionally approximated by variables measuring parental socioeconomic status. The structural position of ethnic groups in society often has implications for the quality of pre-college qualifications and the choice of study subject and institution Arbona and Nora, (2007); Leslie, (2005). Students from less-advantaged minority groups are likely to be less well qualified for higher education and they tend to choose more likely colleges rather than universities which are more prestigious than colleges. In addition, these students often prefer certain study subjects, such as law, business and medicine that are regarded as prestigious in their own ethnic community and that are supposed to provide higher income. In the Netherlands, access to higher education is conditional on the completion of pre-determined secondary education, no entrance examination is needed. Financial constraints play hardly any role in determining student transit to the higher education which may be more relevant for less advantaged ethnic minority groups.

The second line of argument emphasizes the role of structural and cultural constraints implicit in society that generate educational disparities for disadvantaged minorities 
Strayhorn, (2010). Students from racial and ethnic minority groups are more likely to come from disadvantaged families and are thought to lack the relevant social and cultural capital necessary for success in college. Social capital refers to productive relationships or networks that provide access to opportunity or lead to favorable outcomes Coleman, (1988). Cultural capital refers to high-status linguistic and cultural competences like value, preferences and tastes that are inherited from parents, peers and other institutional agents Strayhorn, (2010); Stanton-Salazar, (1997). Deficiency in the proficiency of majority language within a minority group is likely to be an important source of a low level of cultural capital. Students from developing non-western countries, especially Mediterranean students, potentially comprise such a minority group possessing less social and cultural capital owing to their less-advantaged position within Dutch society. A low level of social and cultural capital is associated with a greater cultural distance from the host society, which will potentially hamper establishing relevant connections with individual and collective agents who serve as translators and mediators of dominant cultural values (Bourdieu, 1986; Stanton-Salazar, (1997). Collective cultural agents refer to academic programs, informal peer groups, cultural centers and student organizations while individual agents refer to faculty administrators, staff and other students. (Museus and Quaye (1999) draw attention at the significant role of staff from racial/ethnic minority groups on campuses in bridging social and cultural gap between students and institutions as well as the awareness of college educators regardless of their race and ethnicity about the cultural challenges that minority students face. They show that persistence of racial/ethnic minority students is positively correlated with the extent and intensity of students' connections with cultural agents who share common cultural background with these students.

The third line of research proposes a model in which the quality of the match between the student and the institution plays a central role in explaining student persistence in colleges Arbona and Nora, (2007); Light and Strayer, 2000; Nora and Cabrera, (1996). The quality of student-institution match will vary for minority students if some institutions provide minority-unfriendly social environment while other institutions will offer facilities to meet the specific needs of minority students such as language support, additional supervising and a platform for mutual support among ethnic minority students. Our data include information neither about differences in ethnic-group specific facilities between higher education institutions nor for the quality of student-institution match. Nevertheless, we are able to control for differences in potential effect of institutions on the degree performance in the regression analysis, so that these differences will not affect our estimates of ethnic disparities.

\section{Data and descriptive statistics}

The analysis uses the Central Register of Higher Education (CRIHO) which includes information about the subject of study, type of education (vocational college - $\mathrm{HBO}$, or university -WO), institution of study, and month and year of graduation, in addition to basic personal characteristics such as age, gender and ethnicity. In addition, the study uses data about parental economic position in 1999 which comes from the Social Statistical Database (SSB). The SSB includes variables measuring relevant labor market characteristics of the parents (employment, benefits and taxable income). Both data-sets are derived from individual register data ensuring a high quality of measurement. 
We selected the entire cohort of students in the CRIHO who started in the Dutch higher education system for the first time in 1996, and look at their position in 2005 to determine whether they successfully completed their study. The CRIHO also includes the year of the diploma and the effective enrolment in the higher education so that the duration of study can be calculated in terms of the number of months. Detailed information about students during 10 years from the beginning allows us to identify whether a student changed subject or graduated between 1999 and 2005.

Table 1 shows the covariates used in the analysis and their mean values by ethnic background. Registers distinguish ethnic minority students on the basis of their country of birth and the country of birth of their parents. To be able to conduct statistical analyses, we cluster ethnic minorities into four major ethnic groups that are most homogenous in the Dutch society regarding their proficiency of the Dutch language and their socio economic position. The ethnic groups differ significantly regarding their characteristics and performance. The majority of the ethnic minority students are second generation: they were born in the Netherlands or immigrated before they were six years old. There is a relatively lower percentage of second generation Caribbean students then might be expected, when compared to first generation students. This is possibly related to the fact that the Netherlands attracts a large cohort of first generation Caribbean students, who come explicitly for higher education. The lower percentage of second generation students from non-Western countries might be a reflection of their short immigration history in the Netherlands. Interestingly, the majority of Mediterranean students are male while other groups are mainly composed of female students. The male-biased gender composition of Mediterranean students is likely related to a less favorable position of women in Muslim communities and the skewed-gender balance of the Mediterranean population in the Netherlands owing to immigration flows of predominantly male laborers from Turkey and Morocco in the 1960s and 1970s. This group is also older than the other students, which is an indication of a longer duration of pre-college education among Mediterranean students.

Considering the student performance by ethnic group ten years after starting in higher education, there are great differences. A large share of students started with $\mathrm{HBO}$ and graduated in $\mathrm{HBO}$, while a relatively small share of these students graduated in WO. Although this pattern holds for all ethnic groups, there are interethnic differences. Mediterranean and Caribbean students are more likely to enroll in HBO and more likely to switch to WO while Western students are more likely to choose a study in WO. In general, a study in WO takes longer than a HBO-study. Remarkably, Mediterranean and Caribbean students seem not to benefit from their choice of a relatively short lasting study period. They are also less likely to finish their study compared to the Dutch students. After ten years, about 40 percent of them had not graduated compared with 22 percent of Dutch students, and these may be called dropouts.

The choice of a HBO or WO study is often predetermined by preliminary training as described above. Mediterranean students have more frequently an $\mathrm{MBO}$ preliminary training, attend high vocational education ( $\mathrm{HBO}$ ) and switch to university education (WO). The choice of study subject also differs across ethnic groups. A large share of Mediterranean, Caribbean and ONW students prefer a study in business, economics and law. These non-western groups also have the most disadvantaged parents. Their parents are less likely to be employed, are more likely dependent on welfare benefits 
Table 1 Covariates and mean values by ethnic group

\begin{tabular}{|c|c|c|c|c|c|}
\hline & Dutch & Mediterr. & Caribbean & ONW & Western \\
\hline Woman & 0.51 & 0.45 & 0.55 & 0.50 & 0.52 \\
\hline Age & 19.17 & 20.13 & 19.93 & 19.96 & 19.56 \\
\hline Second generation & & 0.79 & 0.65 & 0.65 & 0.87 \\
\hline \multicolumn{6}{|l|}{ Study } \\
\hline WO-starter & 0.26 & 0.18 & 0.22 & 0.34 & 0.33 \\
\hline HBO to WO switch & 0.10 & 0.12 & 0.13 & 0.11 & 0.09 \\
\hline Duration of study in months & 60.83 & 64.20 & 65.92 & 67.49 & 65.41 \\
\hline Graduated up to 2005 & 0.78 & 0.61 & 0.60 & 0.66 & 0.69 \\
\hline \multicolumn{6}{|l|}{ Preliminary training } \\
\hline HAVO (reference) & 0.34 & 0.34 & 0.36 & 0.31 & 0.30 \\
\hline VWO & 0.39 & 0.21 & 0.31 & 0.34 & 0.39 \\
\hline MBO & 0.23 & 0.30 & 0.23 & 0.13 & 0.16 \\
\hline Other & 0.01 & 0.06 & 0.03 & 0.15 & 0.09 \\
\hline \multicolumn{6}{|l|}{ Subject of study } \\
\hline Social Sciences (reference) & 0.06 & 0.03 & 0.05 & 0.06 & 0.08 \\
\hline Education & 0.14 & 0.11 & 0.09 & 0.07 & 0.11 \\
\hline Humanities & 0.06 & 0.02 & 0.04 & 0.09 & 0.11 \\
\hline Economics \& Law & 0.27 & 0.45 & 0.41 & 0.39 & 0.28 \\
\hline Natural Sciences & 0.21 & 0.15 & 0.19 & 0.21 & 0.19 \\
\hline Health \& Social services & 0.39 & 0.26 & 0.32 & 0.35 & 0.35 \\
\hline \multicolumn{6}{|l|}{ Parents demography in 1999} \\
\hline \# kids living with mother & 1.27 & 1.92 & 0.98 & 1.24 & 1.00 \\
\hline Father and Mother together & 0.84 & 0.79 & 0.41 & 0.58 & 0.66 \\
\hline Mother widowed & 0.03 & 0.05 & 0.02 & 0.04 & 0.03 \\
\hline \multicolumn{6}{|c|}{ Parents' economic position in 1999} \\
\hline Log Father income & 7.35 & 6.22 & 4.26 & 4.89 & 6.01 \\
\hline Log Mother income & 4.43 & 3.79 & 4.53 & 3.89 & 4.39 \\
\hline Mother employed (reference) & 0.55 & 0.14 & 0.45 & 0.35 & 0.49 \\
\hline Mother welfare benefit & 0.04 & 0.33 & 0.14 & 0.16 & 0.08 \\
\hline Mother other benefit & 0.04 & 0.11 & 0.04 & 0.06 & 0.06 \\
\hline Mother housewife & 0.33 & 0.35 & 0.11 & 0.22 & 0.26 \\
\hline No mother & 0.03 & 0.07 & 0.26 & 0.20 & 0.11 \\
\hline Father employed (reference) & 0.81 & 0.28 & 0.42 & 0.44 & 0.60 \\
\hline Father welfare benefit & 0.05 & 0.44 & 0.10 & 0.13 & 0.07 \\
\hline Father other benefit & 0.08 & 0.16 & 0.06 & 0.12 & 0.13 \\
\hline No- father & 0.05 & 0.12 & 0.42 & 0.30 & 0.20 \\
\hline N & 65418 & 1660 & 2431 & 1615 & 5902 \\
\hline
\end{tabular}

and their labor income is the lowest when they are employed. Caribbean students are usually from a small household consisting of a single parent while Mediterranean students are most likely to be from a household in which the number of children is the biggest. The parents of Dutch and Mediterranean students are most likely to be together. For 41 percent of Caribbean students, the father is not present. 


\section{Estimating ethnic disparities}

To identify ethnic differences in student performance in the Dutch higher education, we use non-parametric and parametric survival analyses. Survival models are suitable to simultaneously capture the conditional likelihood of the completion of a degree and the duration of program, rather than frequently employed conventional logit models which consider only the likelihood of a binary outcome, e.g. completion of a degree versus not-completion or persistence versus drop-out.

\section{Non-parametric estimation of degree performance}

In order to describe the duration pattern of study and dropout rate, we start with estimating non-parametric survival models (Kaplan-Meier) for the ethnic groups for the separate study types: $\mathrm{HBO}$ and WO. Figure $2 \mathrm{a}$ and $2 \mathrm{~b}$ indicate that $\mathrm{HBO}$-students graduate quicker than WO-students. However, after ten years a larger share of WO-students has graduated compared with $\mathrm{HBO}$-students. The probability of graduation significantly decreases with time for HBO-students, especially after 60 months, while this remains relatively high for WO-students. In both study types, the performance of Dutch students is the highest. They are followed by Western students, and ONW. Caribbean and Mediterranean students are most likely to drop out and need more time to finish the study.

\section{Parametric model}

The time taken to complete the course of study is given as a continuous random variable, $T$ : and the density and the cumulative distribution functions of $T$ are given by $f(\mathrm{t})$ and $F(\mathrm{t})=P(T \leq t)$. The survival function is defined as $S(t)=P(T \succ t)=1-F(t)$ and the hazard function as $h(\mathrm{t})=f(\mathrm{t}) / S(\mathrm{t})$, which is the conditional probability of finishing the study. We model the duration of study as a parametric survival model which is akin to ordinary linear regression Gutierrez, (2002); Hougaard, (1995). Our initial non-parametric analysis of the data shows smooth and well-behaving survival functions. Thus a parametric model can be expected to fit the data adequately. In addition, a parametric model can be checked relatively easily Lambert et al., (2004). In contrast to proportional hazard models, in the accelerated failure time models, the covariates directly affect the log failure time, rather than the hazard function. In this model, the logarithm of the survival time is given as a linear function of the covariates $\left(x_{i}\right)$. The parametric hazard model is given as:

$$
\ln t_{i}=x_{i} \beta+\varepsilon_{i}
$$

where $\beta$ is a vector of coefficients to be estimated and $\varepsilon_{i}$ is the error term. In this parametric model, the distributional form of the error term needs to be predetermined to estimate the parameters. This form determines the regression model. The investigation of the underlying distribution shows that a generalized gamma regression model fits our data best. To select the best fitting model, we fitted parametric models with exponential, log-logistic, log normal and gamma distribution separately. Subsequently, we conducted post-estimation tests such as likelihood ratio and Wald tests as well as Akaike information criteria (AIC) Lambert et al., (2004; Gutierrez, (2002). The generalized 


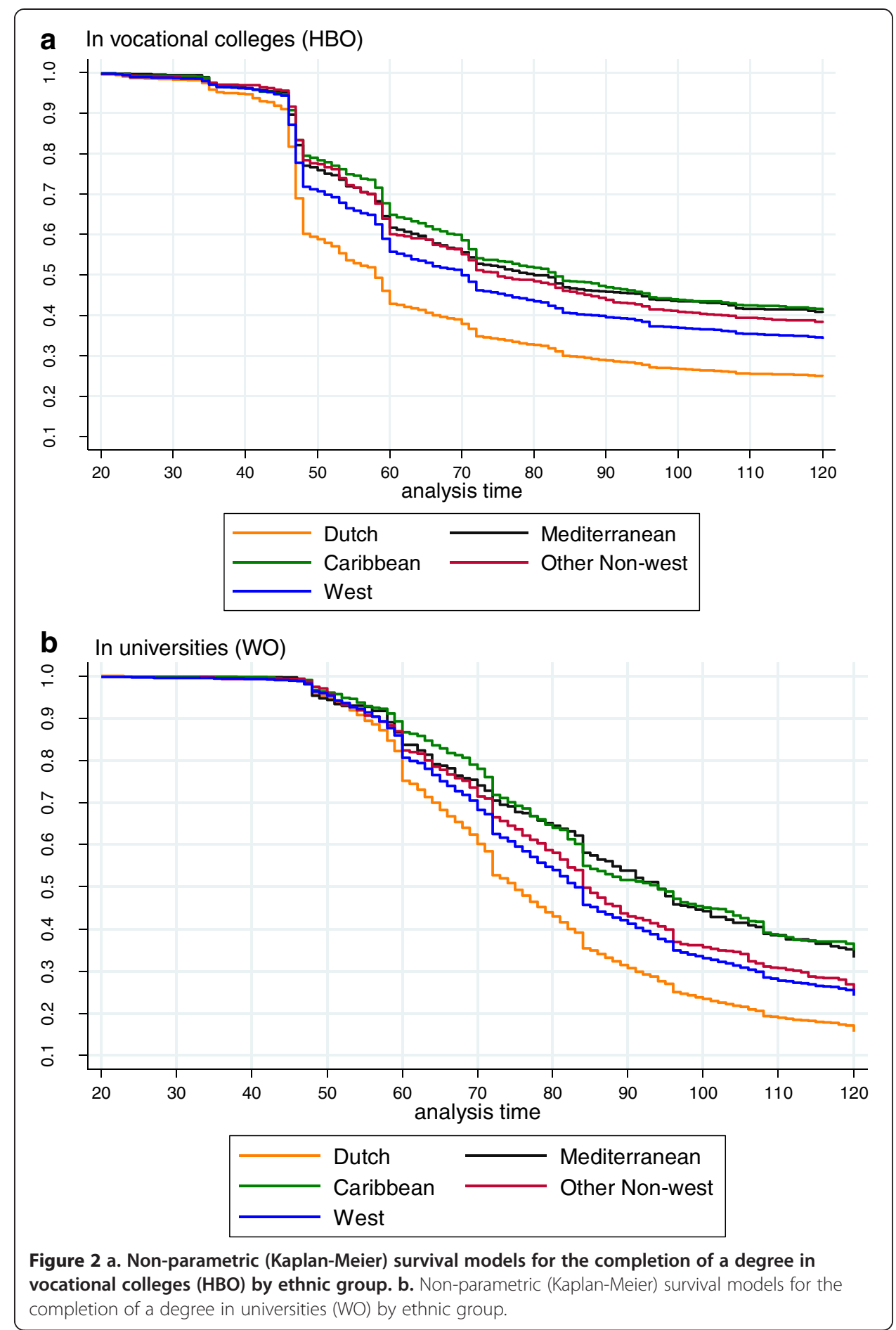

gamma distribution has one scale parameter $(\mu)$ and two shape parameters $(k$ and $\sigma)$. The density function for the generalized gamma distribution is given as

$$
f\left(t_{i}, \varepsilon_{i}\right)=\frac{\gamma^{\gamma}}{\sigma t \sqrt{\gamma} \Gamma(\gamma)} \exp (\varepsilon \sqrt{\gamma}-u), \quad \text { if } \kappa \neq 0
$$

where $\gamma=|\kappa|^{-2}, \varepsilon=\operatorname{sign}(\kappa)\{\ln (t)-\mu\} / \sigma$ and $u=\gamma \exp (|\kappa| \varepsilon)$. The hazard function of the generalized gamma distribution is extremely flexible, allowing a large number of shapes. For 
instance: when the shape parameter $k=0$, the density function reduces to the standard normal distribution for $\varepsilon$. When the shape parameter kappa equals $1(k=1)$, it reduces to the standard extreme-value distribution. If $k=1$ and $\sigma=1$, then $t$ has an exponential distribution as a special case of the Weibull distribution, etc.

\section{A frailty model}

Model (2) will not provide consistent estimates if there are unobserved students' characteristics that affect the hazard of graduation. To address individual heterogeneity, we consider a frailty model for students of $\mathrm{HBO}$ and WO, as described by (Gutierrez 2002) and (Hougaard 1995). A frailty model considers an unobservable multiplicative effect $k$ on the hazard, so that conditional on the frailty:

$$
h(t \mid k)=k h(t)
$$

where $k$ is some positive quantity assumed to have mean one and variance $\theta$. Individuals having $k \succ 1$ will have an increased risk of finishing their study for reasons which can not be explained by the covariates. Individuals with $k \prec 1$ will survive longer for reasons that are unobserved.

The survival function can be written as:

$$
S(t \mid k)=\{S(t)\}^{k}
$$

Since $k$ is not observed, it must be integrated out of (4). When $k$ is assumed to be distributed as an inverse Gaussian, the population survival function becomes:

$$
S_{\theta}(t)=\exp \left\{\frac{1}{\theta}\left(1-[1-2 \theta \ln \{S(t)\}]^{1 / 2}\right)\right\}
$$

We start with estimating separate duration models for students who started with $\mathrm{HBO}$ and WO acknowledging a distinct pattern of performance of $\mathrm{HBO}$ and WO students as shown by Figure 2. For both groups, we estimate two models: the first model (basic model) includes individual demographic variables and the subject of study. The second model (extended model) includes additional variables which measure the socioeconomic position of both parents. This strategy is applied to isolate the impact of parental background, because immigrant background is strongly correlated with socioeconomic position. In view of the well-established correlation between educational achievement and parental socio-economic position, it would be informative to identify the influence of parental background on student performance in higher education.

Subsequently, we account for unobserved heterogeneities in the population that may affect the size of the ethnic performance gap, since available variables are unlikely to capture all relevant factors affecting individual study performance. Therefore, we estimate a similar model with a component for unobserved heterogeneity assuming an inverse Gaussian frailty structure, as described by (3).

\section{Results of parametric models}

The parameter estimates of separate duration models for students who started with HBO and WO are presented in Table 2. The estimated coefficients are given in an accelerated failure time metric, which adjusts survival functions for the effects of covariates. For the sake of interpretation, we sometimes interchangeably use the term 
Table 2 Estimates of the conditional probability of completing a degree in HBO and WO: the estimated coefficients are given in accelerated failure time metric (standard errors in parentheses)

\begin{tabular}{|c|c|c|c|c|}
\hline & HBO & HBO extended & wo & WO extended \\
\hline \multirow[t]{2}{*}{ Mediterrenean } & $0.141^{* * *}$ & $0.129^{* * *}$ & $0.094^{* * *}$ & $0.096^{* * *}$ \\
\hline & $(0.016)$ & $(0.016)$ & $(0.026)$ & $(0.027)$ \\
\hline \multirow[t]{2}{*}{ Caribbean } & $0.153^{* * *}$ & $0.128^{* * *}$ & $0.130^{* * *}$ & $0.118^{* * *}$ \\
\hline & $(0.018)$ & $(0.016)$ & $(0.021)$ & $(0.020)$ \\
\hline \multirow[t]{2}{*}{ Other non-western } & $0.088^{* *}$ & $0.078^{*}$ & $0.086^{* * *}$ & $0.080^{* * *}$ \\
\hline & $(0.032)$ & $(0.031)$ & $(0.016)$ & $(0.016)$ \\
\hline \multirow[t]{2}{*}{ Western } & $0.064^{* * *}$ & $0.052^{* *}$ & $0.036^{* * *}$ & $0.029^{* * *}$ \\
\hline & $(0.018)$ & $(0.016)$ & $(0.007)$ & $(0.007)$ \\
\hline \multirow[t]{2}{*}{ Girl } & $-0.105^{* * *}$ & $-0.107^{* * *}$ & $-0.120^{* * *}$ & $-0.121^{* * *}$ \\
\hline & $(0.011)$ & $(0.011)$ & $(0.011)$ & $(0.011)$ \\
\hline \multirow[t]{2}{*}{ Age } & $-0.038^{* * *}$ & $-0.040^{* * *}$ & $0.020^{* * *}$ & $0.017^{* *}$ \\
\hline & $(0.006)$ & $(0.006)$ & $(0.006)$ & $(0.006)$ \\
\hline \multirow[t]{2}{*}{ Preliminary Training: WWO } & -0.017 & -0.016 & 0.051 & 0.057 \\
\hline & $(0.010)$ & $(0.010)$ & $(0.049)$ & $(0.049)$ \\
\hline \multirow[t]{2}{*}{ Preliminary Training: MBO } & $-0.064^{* *}$ & $-0.063^{* *}$ & & \\
\hline & $(0.023)$ & $(0.023)$ & & \\
\hline \multirow[t]{2}{*}{ Preliminary Training: Other } & -0.040 & -0.042 & -0.089 & -0.080 \\
\hline & $(0.042)$ & $(0.040)$ & $(0.087)$ & $(0.080)$ \\
\hline \multirow[t]{2}{*}{ Education } & 0.032 & 0.035 & $-0.122^{* * *}$ & $-0.115^{* * *}$ \\
\hline & $(0.024)$ & $(0.022)$ & $(0.029)$ & $(0.030)$ \\
\hline \multirow[t]{2}{*}{ Humanities } & 0.063 & 0.057 & $0.066^{* * *}$ & $0.067^{* * *}$ \\
\hline & $(0.034)$ & $(0.033)$ & $(0.019)$ & $(0.019)$ \\
\hline \multirow[t]{2}{*}{ Economics \& Law } & -0.017 & -0.014 & -0.006 & -0.002 \\
\hline & $(0.044)$ & $(0.043)$ & $(0.011)$ & $(0.010)$ \\
\hline \multirow[t]{2}{*}{ Natural Sciences } & $0.131^{* *}$ & $0.133^{* *}$ & 0.055 & 0.055 \\
\hline & $(0.048)$ & $(0.047)$ & $(0.032)$ & $(0.032)$ \\
\hline \multirow[t]{2}{*}{ Health \& Social Services } & $-0.180^{* * *}$ & $-0.178^{* * *}$ & -0.028 & -0.024 \\
\hline & $(0.049)$ & $(0.048)$ & $(0.020)$ & $(0.019)$ \\
\hline \multirow[t]{2}{*}{ \# children living with mother } & & $-0.009^{* *}$ & & $-0.009^{* * *}$ \\
\hline & & $(0.003)$ & & $(0.002)$ \\
\hline \multirow[t]{2}{*}{ Parents living together } & & $-0.052^{* * *}$ & & $-0.065^{* * *}$ \\
\hline & & $(0.009)$ & & $(0.012)$ \\
\hline \multirow[t]{2}{*}{ Mother widowed } & & -0.055 & & $-0.052^{* * *}$ \\
\hline & & $(0.032)$ & & $(0.016)$ \\
\hline \multirow[t]{2}{*}{ Log Father's income } & & -0.001 & & -0.000 \\
\hline & & $(0.002)$ & & $(0.002)$ \\
\hline \multirow[t]{2}{*}{ Log Mother's income } & & $0.007^{* *}$ & & 0.003 \\
\hline & & $(0.002)$ & & $(0.003)$ \\
\hline \multirow[t]{2}{*}{ Mother on welfare benefit } & & $0.027^{* * *}$ & & $0.035^{* *}$ \\
\hline & & $(0.007)$ & & $(0.011)$ \\
\hline \multirow[t]{2}{*}{ Mother on other benefit } & & 0.017 & & 0.008 \\
\hline & & $(0.015)$ & & $(0.008)$ \\
\hline
\end{tabular}


Table 2 Estimates of the conditional probability of completing a degree in HBO and WO: the estimated coefficients are given in accelerated failure time metric (standard errors in parentheses) (Continued)

\begin{tabular}{|c|c|c|c|c|}
\hline \multirow[t]{2}{*}{ Mother Housewife } & & $0.034^{*}$ & & 0.022 \\
\hline & & $(0.014)$ & & $(0.024)$ \\
\hline \multirow[t]{2}{*}{ Mother not present } & & -0.001 & & -0.033 \\
\hline & & $(0.024)$ & & $(0.028)$ \\
\hline \multirow[t]{2}{*}{ Father self-employed } & & -0.000 & & $0.026^{* * *}$ \\
\hline & & $(0.008)$ & & $(0.007)$ \\
\hline \multirow[t]{2}{*}{ Father on welfare benefit } & & $0.025^{* *}$ & & -0.013 \\
\hline & & $(0.009)$ & & $(0.012)$ \\
\hline \multirow[t]{2}{*}{ Father on other benefit } & & 0.009 & & $0.034^{* *}$ \\
\hline & & $(0.007)$ & & $(0.012)$ \\
\hline \multirow[t]{2}{*}{ Father not present } & & 0.002 & & -0.005 \\
\hline & & $(0.022)$ & & $(0.023)$ \\
\hline \multirow[t]{2}{*}{ Switched HBO to WO } & $0.042^{* * *}$ & $0.038^{* * *}$ & & \\
\hline & $(0.011)$ & $(0.011)$ & & \\
\hline \multirow[t]{2}{*}{ Switched WO to HBO } & & & 0.018 & 0.016 \\
\hline & & & $(0.015)$ & $(0.015)$ \\
\hline \multirow[t]{2}{*}{ Constant } & $4.745^{* * *}$ & $4.815^{* * *}$ & $3.896^{* * *}$ & $3.983^{* * *}$ \\
\hline & $(0.111)$ & $(0.112)$ & $(0.092)$ & $(0.114)$ \\
\hline \multirow[t]{2}{*}{$\operatorname{Ln} \sigma$} & $-0.894^{* * *}$ & $-0.896^{* * *}$ & $-1.161^{* * *}$ & $-1.167^{* * *}$ \\
\hline & $(0.025)$ & $(0.025)$ & $(0.038)$ & $(0.038)$ \\
\hline \multirow[t]{2}{*}{ k } & $-1.709^{* * *}$ & $-1.706^{* * *}$ & $-0.735^{* * *}$ & $-0.747^{* * *}$ \\
\hline & $(0.068)$ & $(0.067)$ & $(0.141)$ & $(0.141)$ \\
\hline \multirow[t]{2}{*}{$\sigma$} & $0.409^{* * *}$ & $0.408^{* * *}$ & $0.313^{* * *}$ & 0.311 \\
\hline & $(0.010)$ & $(0.010)$ & $(0.012)$ & $(0.012)$ \\
\hline Log (pseudo) likelihood & -41995.33 & -41871.35 & -8178.04 & -8098.43 \\
\hline Wald $X^{2}$ & 1332.29 & 10112.07 & 27945.99 & 1537998.52 \\
\hline N & 56761 & 56761 & 20265 & 20265 \\
\hline
\end{tabular}

* $\mathrm{p}<0.05$; ** $\mathrm{p}<0.01$; *** $\mathrm{p}<0.001$.

Standard errors are adjusted for the clustering of students in institutions.

likelihood, instead of hazard which refers to conditional likelihood as discussed above. Ethnic groups from non-western origins (Mediterranean, Caribbeans, other nonwestern) have a significant lower likelihood of graduation compared with Dutch students (the reference group). Western students perform better than non-western, but they still have a lower likelihood than Dutch students. A comparison of the basic and extended models for HBO (the first and second columns), as well as for WO (the third and fourth columns), indicates that including parental background variables leads to only modest decline in the ethnic performance gap, especially for HBO. Parental socioeconomic position has no effect on the performance gap between Dutch and Mediterranean students in WO. So, the estimated ethnic performance gaps referring to a lower likelihood of graduation are robust to differences in parental socio-economic position. Since institutional environment is evidenced to be influential for students' performance, we account for differences between the institutions by correcting standard errors for clustering in institutions ${ }^{2}$. 
The subject of study appears to be important. Among HBO studies, a study in natural sciences lasts much longer compared with social sciences (the reference category) while a study in health \& social services needs less time. Among WO studies, the likelihood of graduation is significantly higher for educational studies while the likelihood for humanities is lower. Students whose parents are together have a higher likelihood of graduation given the number of children in the household, compared to the reference category: parents are alive but not together. The impact of parents' economic position on performance is limited. If the mother is on social welfare or a house-wife, the student is less likely to graduate compared to students with an employed mother (the reference). Fathers' economic position has, however, no significant effect on a child's study performance. Furthermore, switching form a $\mathrm{HBO}$ study to a WO study appears to need more time while the opposite does not hold, as expected.

\section{Unobserved heterogeneity}

After considering the differences between $\mathrm{HBO}$ and WO studies, we aim now to estimate general ethnic performance gaps in the Dutch higher education pooling both student populations. Using controls for $\mathrm{HBO}$ and WO-studies, we estimate a parametric duration model with an unobserved heterogeneity component based on the pooled population in addition to a basic parametric duration model. A comparison of the model with and without frailty suggests that ethnic performance gaps become slightly smaller after controlling for unobserved heterogeneity but remain statistically significant (see Table 3).

The estimated parameters for ethnic minority groups are less informative when hazards over time are considered. To see the shape of the hazard functions, we plot the hazard functions for $\mathrm{HBO}$ and $\mathrm{WO}$ by gender and ethnicity, based on the extended conditional frailty model for the pooled population. Since the largest ethnic disparities are found for Mediterranean and Caribbean students, we consider the hazard of graduation for these groups in comparison with Dutch students. Figures 3a-3d show the hazard functions for $\mathrm{HBO}$ and WO by gender and ethnic origin. It immediately appears that there are marked differences in the shape of the hazard functions of Mediterranean and Caribbean students on the one hand, and Dutch students on the other hand, both in HBO and in WO. Within each sub-category, the hazard of Mediterranean students lies systematically below the hazard functions of Dutch students. The differences in the hazard rates are more pronounced for the slightly different periods for WO and HBO: between the $30^{\text {th }}$ and the $60^{\text {th }}$ month for $\mathrm{HBO}$, and between the $30^{\text {th }}$ month and the $70^{\text {th }}$ month for WO. More specifically, Figure $3 \mathrm{a}$ and $3 \mathrm{~b}$ show that the hazard of graduation is significantly higher for Dutch women than that of Mediterranean and Caribbean women. Figure 3c and 3d reflect similar disparities for Mediterranean and Caribbean men, compared with Dutch men. Furthermore, there are obvious differences between the hazard of graduation of men and women as well as between the hazard of graduation of students in HBO and WO studies. Female students have a hazard function rising steeper than male students' hazard function, and the hazard function of $\mathrm{HBO}$-students is much steeper than that of $\mathrm{WO}$, indicating higher hazards of graduation for women and $\mathrm{HBO}$-students, as discussed before.

\section{Determinants of performance across ethnic groups}

Since the share of ethnic minorities is small in the student population, background characteristics of Dutch students may dominate estimates. To verify the impact of variables 
Table 3 Estimates of the conditional probability of completing a degree in HBO and WO

\begin{tabular}{|c|c|c|c|c|}
\hline & Without UH & & With UH & \\
\hline & Basic & Extended & Basic & Extended \\
\hline \multirow[t]{2}{*}{ Mediterranean } & $0.145^{* * *}$ & $0.136^{* * *}$ & $0.118^{* * *}$ & $0.115^{* * *}$ \\
\hline & $(0.016)$ & $(0.016)$ & $(0.016)$ & $(0.015)$ \\
\hline \multirow[t]{2}{*}{ Caribbean } & $0.153^{* * *}$ & $0.130^{* * *}$ & $0.128^{* * *}$ & $0.109^{* * *}$ \\
\hline & $(0.016)$ & $(0.013)$ & $(0.015)$ & $(0.012)$ \\
\hline \multirow[t]{2}{*}{ Other non-western } & $0.102^{* * *}$ & $0.093^{* * *}$ & $0.091^{* * *}$ & $0.084^{* * *}$ \\
\hline & $(0.021)$ & $(0.020)$ & $(0.017)$ & $(0.016)$ \\
\hline \multirow[t]{2}{*}{ Western } & $0.059^{* * *}$ & $0.048^{* * *}$ & $0.053^{* * *}$ & $0.043^{* * *}$ \\
\hline & $(0.014)$ & $(0.012)$ & $(0.010)$ & $(0.009)$ \\
\hline \multirow[t]{2}{*}{ Woman } & $-0.110^{* * *}$ & $-0.111^{* * *}$ & $-0.097^{* * *}$ & $-0.098^{* * *}$ \\
\hline & $(0.009)$ & $(0.009)$ & $(0.009)$ & $(0.009)$ \\
\hline \multirow[t]{2}{*}{ Age } & $-0.032^{* * *}$ & $-0.035^{* * *}$ & $-0.033^{* * *}$ & $-0.036^{* * *}$ \\
\hline & $(0.006)$ & $(0.006)$ & $(0.007)$ & $(0.007)$ \\
\hline \multirow[t]{2}{*}{ WO-start } & $0.263^{* * *}$ & $0.260^{* * *}$ & $0.260^{* * *}$ & $0.256^{* * *}$ \\
\hline & $(0.015)$ & $(0.015)$ & $(0.016)$ & $(0.015)$ \\
\hline \multirow[t]{2}{*}{ Switched HBO to WO } & $0.050^{* * *}$ & $0.047^{* * *}$ & $0.056^{* * *}$ & $0.053^{* * *}$ \\
\hline & $(0.010)$ & $(0.010)$ & $(0.008)$ & $(0.008)$ \\
\hline \multirow[t]{2}{*}{ Preliminary Training: WWO } & $-0.027^{* * *}$ & $-0.026^{* * *}$ & $-0.016^{*}$ & -0.015 \\
\hline & $(0.009)$ & $(0.009)$ & $(0.010)$ & $(0.010)$ \\
\hline \multirow[t]{2}{*}{ Preliminary Training: MBO } & $-0.073^{* * *}$ & $-0.072^{* * *}$ & $-0.081^{* * *}$ & $-0.079^{* * *}$ \\
\hline & $(0.024)$ & $(0.024)$ & $(0.025)$ & $(0.025)$ \\
\hline \multirow[t]{2}{*}{ Preliminary Training: Other } & $-0.087^{* *}$ & $-0.086^{* *}$ & -0.057 & $-0.058^{*}$ \\
\hline & $(0.042)$ & $(0.038)$ & $(0.035)$ & $(0.031)$ \\
\hline \multirow[t]{2}{*}{ Education } & 0.027 & 0.031 & 0.012 & 0.017 \\
\hline & $(0.033)$ & $(0.031)$ & $(0.023)$ & $(0.022)$ \\
\hline \multirow[t]{2}{*}{ Humanities } & 0.058 & 0.055 & $0.049^{*}$ & $0.048^{*}$ \\
\hline & $(0.036)$ & $(0.034)$ & $(0.026)$ & $(0.025)$ \\
\hline \multirow[t]{2}{*}{ Economics \& Law } & -0.009 & -0.007 & -0.015 & -0.011 \\
\hline & $(0.043)$ & $(0.041)$ & $(0.032)$ & $(0.031)$ \\
\hline \multirow[t]{2}{*}{ Natural Sciences } & -0.031 & -0.027 & -0.031 & -0.026 \\
\hline & $(0.038)$ & $(0.036)$ & $(0.029)$ & $(0.028)$ \\
\hline \multirow[t]{2}{*}{ Health \& Social Services } & $-0.105^{* *}$ & $-0.104^{* *}$ & $-0.102^{* *}$ & $-0.099^{* *}$ \\
\hline & $(0.048)$ & $(0.046)$ & $(0.040)$ & $(0.039)$ \\
\hline \multirow[t]{2}{*}{ \# children living with mother } & & $-0.010^{* * *}$ & & $-0.010^{* * *}$ \\
\hline & & $(0.002)$ & & $(0.002)$ \\
\hline \multirow[t]{2}{*}{ Parents living together } & & $-0.061^{* * *}$ & & $-0.048^{* * *}$ \\
\hline & & $(0.008)$ & & $(0.007)$ \\
\hline \multirow[t]{2}{*}{ Mother widowed } & & $-0.066^{* * *}$ & & $-0.061^{* * *}$ \\
\hline & & $(0.025)$ & & $(0.021)$ \\
\hline \multirow[t]{2}{*}{ Log Father's income } & & -0.001 & & -0.001 \\
\hline & & $(0.001)$ & & $(0.001)$ \\
\hline \multirow[t]{2}{*}{ Log Mother's income } & & $0.007^{* * *}$ & & $0.006^{* * *}$ \\
\hline & & $(0.002)$ & & $(0.002)$ \\
\hline
\end{tabular}


Table 3 Estimates of the conditional probability of completing a degree in HBO and WO (Continued)

\begin{tabular}{|c|c|c|c|c|}
\hline \multirow[t]{2}{*}{ Mother on welfare benefit } & & \multicolumn{2}{|l|}{$0.031^{* * *}$} & $0.022^{* * *}$ \\
\hline & & \multicolumn{2}{|l|}{$(0.007)$} & $(0.006)$ \\
\hline \multirow{2}{*}{\multicolumn{2}{|c|}{ Mother on other benefit }} & \multicolumn{2}{|l|}{$0.019^{*}$} & 0.014 \\
\hline & & \multicolumn{2}{|l|}{$(0.011)$} & (0.009) \\
\hline \multirow{2}{*}{\multicolumn{2}{|c|}{ Mother Housewife }} & \multicolumn{2}{|l|}{$0.040^{* * *}$} & $0.036^{* * *}$ \\
\hline & & \multicolumn{2}{|l|}{$(0.013)$} & $(0.011)$ \\
\hline \multirow{2}{*}{\multicolumn{2}{|c|}{ Mother not present }} & \multicolumn{2}{|l|}{-0.005} & -0.001 \\
\hline & & \multicolumn{2}{|l|}{$(0.020)$} & $(0.016)$ \\
\hline \multirow{2}{*}{\multicolumn{2}{|c|}{ Father on welfare benefit }} & \multicolumn{2}{|l|}{$0.018^{* *}$} & 0.009 \\
\hline & & \multicolumn{2}{|l|}{$(0.008)$} & $(0.007)$ \\
\hline \multirow{2}{*}{\multicolumn{2}{|c|}{ Father on other benefit }} & \multicolumn{2}{|l|}{0.012} & 0.010 \\
\hline & & \multicolumn{2}{|l|}{$(0.007)$} & $(0.006)$ \\
\hline \multirow[t]{2}{*}{ Father not present } & & \multicolumn{2}{|l|}{-0.008} & -0.003 \\
\hline & & \multicolumn{2}{|l|}{$(0.019)$} & $(0.014)$ \\
\hline \multirow[t]{2}{*}{ Constant } & $4.657^{* * *}$ & $4.736^{* * *}$ & $4.678^{* * *}$ & $4.752^{* * *}$ \\
\hline & $(0.127)$ & $(0.127)$ & $(0.141)$ & $(0.141)$ \\
\hline \multirow[t]{2}{*}{$\operatorname{Ln} \sigma$} & $-0.936^{* * *}$ & $-0.938^{* * *}$ & $-1.326^{* * *}$ & $-1.328^{* * *}$ \\
\hline & $(0.031)$ & $(0.031)$ & $(0.048)$ & $(0.048)$ \\
\hline \multirow[t]{2}{*}{ k } & $-1.490^{* * *}$ & $-1.488^{* * *}$ & $-0.587^{* * *}$ & $-0.588^{* * *}$ \\
\hline & $(0.073)$ & $(0.072)$ & $(0.049)$ & $(0.049)$ \\
\hline \multirow[t]{2}{*}{$\sigma$} & $0.392^{* * *}$ & $0.391^{* * *}$ & $0.265^{* * *}$ & $0.265^{* * *}$ \\
\hline & $(0.012)$ & $(0.012)$ & $(0.013)$ & $(0.013)$ \\
\hline \multirow[t]{2}{*}{$\operatorname{Ln} \theta$} & & & $0.701^{* * *}$ & $0.694^{* * *}$ \\
\hline & & & $(0.077)$ & $(0.077)$ \\
\hline \multirow[t]{2}{*}{$\theta$} & & & 2.016 & $2.002^{* * *}$ \\
\hline & & & $(0.155)$ & $(0.154)$ \\
\hline Log (pseudo) likelihood & -52634.39 & -52432.95 & -49954.72 & -49780.84 \\
\hline Wald X2 & 1516.17 & 6025.16 & 1454.13 & 4933.61 \\
\hline $\mathrm{N}$ & 77026 & 77026 & 77026 & 77026 \\
\hline
\end{tabular}

${ }^{*} \mathrm{p}<.1 ; * * \mathrm{p}<.05 ; * * * \mathrm{p}<.01$.

Standard errors are in parentheses and adjusted for the clustering of students in institutions.

The results from parametric hazard models with and without unobserved heterogeneity component: the coefficients are given in accelerated failure time metric.

within ethnic groups, we estimate separate parametric duration models for Mediterranean, Caribbean and Western in addition to Dutch. For each ethnic group, we estimate a model without correction for unobserved heterogeneity (Without) and another model with correction for unobserved heterogeneity (With $\mathrm{UH}$ ), except for Caribbeans for whom a frailty model does not converge. Taking into account unobserved heterogeneity does not lead to large shifts in parameter estimates. The models with correction for unobserved heterogeneity generate only slightly different coefficients. From a comparison of these two models for other ethnic groups, we can assess, however that possible biases due to unobserved heterogeneity would be modest.

Female students have a higher hazard of graduation for all ethnic groups but the gender difference is the largest for Dutch and Western students. Second generation ethnic minority students also have a higher hazard of graduation. Strikingly, the choice of 


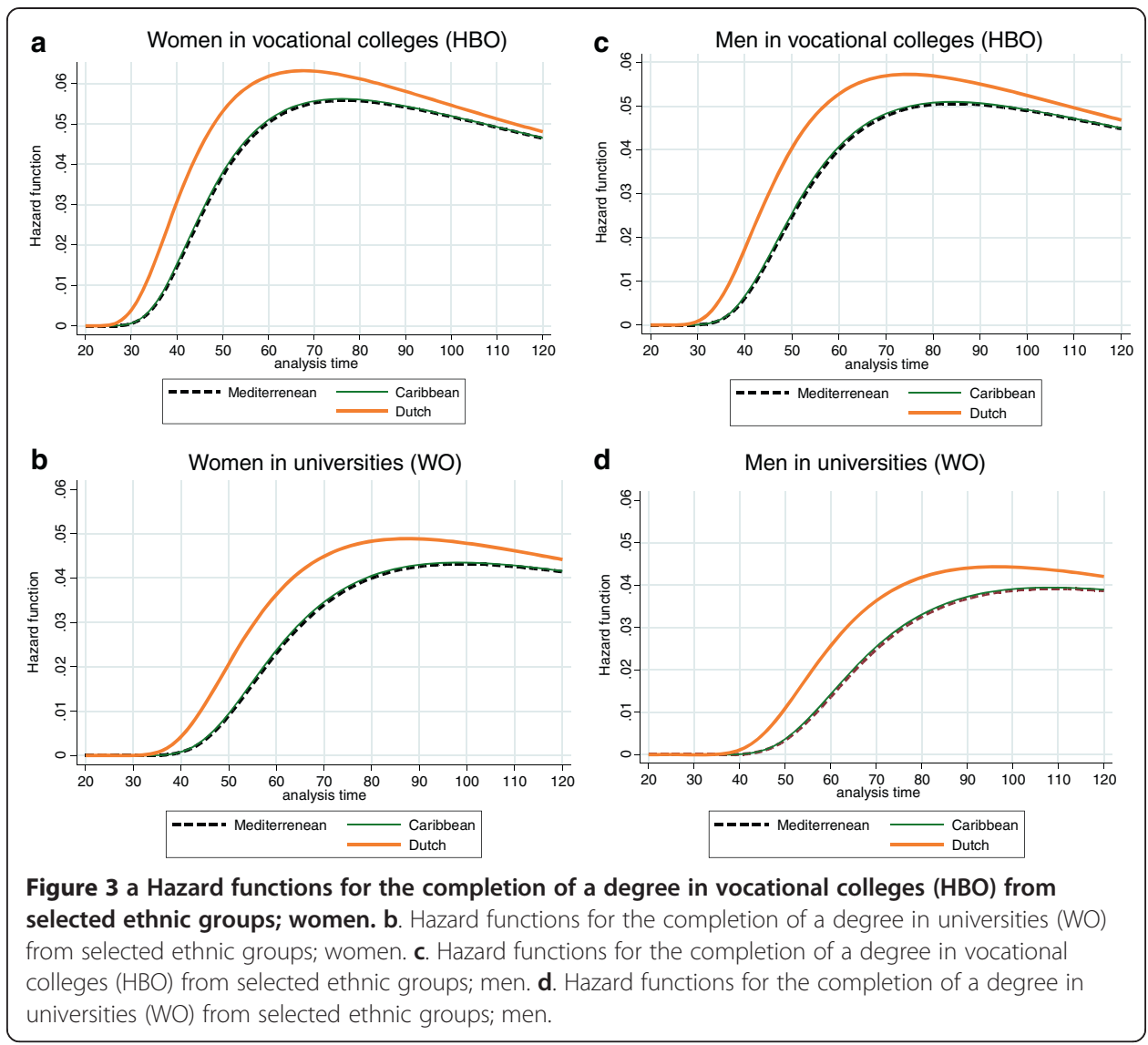

study subject has little relevance for ethnic minority students. Mediterranean students attending a study in natural sciences, and Caribbean and Western students attending health and social services have a higher hazard of graduation than those who study a course in social sciences. Their high concentration in economic studies and law has little to do with their low performance. For Dutch students, the study subject is more often a predictor of study performance. Those who study humanities, education and social sciences have a lower performance than other Dutch students who have chosen a course in social sciences. Also the impact of parental background has little importance for the performance of Mediterranean and Caribbean students (Table 4).

\section{Conclusions}

Using unique individual administrative data of the intake cohort 1996 in Dutch higher education, this paper examined the hazard of successfully completing a study in colleges and universities within ten years. We first estimated non-parametric duration models to describe the pattern of survival functions across ethnic groups. Subsequently, we applied parametric duration models to alternative populations, decomposed on the basis of the type of study ( $\mathrm{HBO}$ and $\mathrm{WO}$ ) and ethnicity. Acknowledging that our administrative data do not include some relevant covariates that can potentially predict degree performance, such as ability, the estimates are corrected for unobserved individual heterogeneity. 
Table 4 Estimates of the conditional probability of completing a degree by ethnic group

\begin{tabular}{|c|c|c|c|c|c|c|c|}
\hline \multirow[t]{2}{*}{ Variable } & \multicolumn{2}{|c|}{ Mediterranean } & \multirow{2}{*}{$\begin{array}{c}\text { Caribbean } \\
\text { Without }\end{array}$} & \multicolumn{2}{|c|}{ Western } & \multicolumn{2}{|c|}{ Dutch } \\
\hline & Without & With UH & & Without & With UH & Without & With UH \\
\hline \multirow[t]{2}{*}{ Woman } & $-0.091^{* * *}$ & $-0.061^{* * *}$ & $-0.074^{* * *}$ & $-0.113^{* * *}$ & $-0.098^{* * *}$ & $-0.113^{* * *}$ & $-0.099 * * *$ \\
\hline & $(0.023)$ & $(0.021)$ & $(0.022)$ & $(0.013)$ & $(0.012)$ & $(0.003)$ & $(0.003)$ \\
\hline \multirow[t]{2}{*}{ Age } & $-0.029^{* * *}$ & $-0.024^{* * *}$ & $-0.033^{* * *}$ & $-0.025^{* * *}$ & $-0.025^{* * *}$ & $-0.038^{* * *}$ & $-0.039^{* * *}$ \\
\hline & $(0.008)$ & $(0.007)$ & $(0.006)$ & $(0.004)$ & $(0.004)$ & $(0.001)$ & $(0.001)$ \\
\hline \multirow[t]{2}{*}{ Second generation } & $-0.073^{* *}$ & $-0.055^{* *}$ & $-0.076^{* * *}$ & $0.102^{* * *}$ & $0.083^{* * *}$ & & \\
\hline & $(0.029)$ & $(0.026)$ & $(0.027)$ & $(0.027)$ & $(0.025)$ & & \\
\hline \multirow[t]{2}{*}{ WO-start } & $0.157^{* * *}$ & $0.171^{* * *}$ & $0.259^{* * *}$ & $0.230^{* * *}$ & $0.236^{* * *}$ & $0.265^{* * *}$ & $0.260^{* * *}$ \\
\hline & $(0.048)$ & $(0.043)$ & $(0.037)$ & $(0.019)$ & $(0.017)$ & $(0.005)$ & $(0.004)$ \\
\hline \multirow[t]{2}{*}{ Switched HBO to WO } & -0.046 & -0.020 & $-0.063^{* *}$ & -0.004 & 0.011 & $0.065^{* * *}$ & $0.066^{* * *}$ \\
\hline & $(0.033)$ & $(0.028)$ & $(0.031)$ & $(0.022)$ & $(0.019)$ & $(0.005)$ & $(0.005)$ \\
\hline \multirow[t]{2}{*}{ Preliminary Training: VWO } & 0.042 & 0.036 & $-0.110^{* * *}$ & $-0.057^{* * *}$ & $-0.046^{* * *}$ & $-0.022^{* * *}$ & $-0.012^{* * *}$ \\
\hline & $(0.046)$ & $(0.040)$ & $(0.034)$ & $(0.019)$ & $(0.017)$ & $(0.005)$ & $(0.004)$ \\
\hline \multirow[t]{2}{*}{ Preliminary Training: MBO } & -0.042 & $-0.059^{* *}$ & $-0.103^{* * *}$ & $-0.077^{* * *}$ & $-0.089^{* * *}$ & $-0.070^{* * *}$ & $-0.076^{* * *}$ \\
\hline & $(0.030)$ & $(0.027)$ & $(0.027)$ & $(0.019)$ & $(0.018)$ & $(0.004)$ & $(0.004)$ \\
\hline \multirow[t]{2}{*}{ Preliminary Training: Other } & $0.210^{* * *}$ & $0.184^{* * *}$ & $-0.261^{* * *}$ & -0.046 & -0.042 & $-0.040^{* *}$ & $-0.031^{* *}$ \\
\hline & $(0.051)$ & $(0.047)$ & $(0.060)$ & $(0.030)$ & $(0.028)$ & $(0.017)$ & $(0.016)$ \\
\hline \multirow[t]{2}{*}{ Education } & 0.028 & 0.009 & -0.019 & 0.034 & 0.017 & $0.029^{* * *}$ & $0.015^{* *}$ \\
\hline & $(0.070)$ & $(0.061)$ & $(0.055)$ & $(0.029)$ & $(0.027)$ & $(0.007)$ & $(0.006)$ \\
\hline \multirow[t]{2}{*}{ Humanities } & -0.117 & -0.133 & 0.070 & -0.012 & -0.010 & $0.073^{* * *}$ & $0.061^{* * *}$ \\
\hline & $(0.091)$ & $(0.082)$ & $(0.066)$ & $(0.028)$ & $(0.026)$ & $(0.008)$ & $(0.007)$ \\
\hline \multirow[t]{2}{*}{ Economics \& Law } & -0.015 & -0.010 & -0.037 & 0.026 & 0.017 & $-0.016^{* *}$ & $-0.018^{* * *}$ \\
\hline & $(0.062)$ & $(0.055)$ & $(0.047)$ & $(0.024)$ & $(0.022)$ & $(0.007)$ & $(0.006)$ \\
\hline \multirow[t]{2}{*}{ Natural Sciences } & $-0.118^{*}$ & $-0.100^{*}$ & -0.053 & -0.018 & -0.014 & $-0.032^{* * *}$ & $-0.030^{* * *}$ \\
\hline & $(0.067)$ & $(0.060)$ & $(0.051)$ & $(0.026)$ & $(0.024)$ & $(0.007)$ & $(0.006)$ \\
\hline \multirow[t]{2}{*}{ Health \& Social Services } & -0.076 & -0.090 & $-0.205^{* * *}$ & $-0.137^{* * *}$ & $-0.123^{* * *}$ & $-0.104^{* * *}$ & $-0.099^{* * *}$ \\
\hline & $(0.065)$ & $(0.058)$ & $(0.049)$ & $(0.025)$ & $(0.023)$ & $(0.007)$ & $(0.006)$ \\
\hline \multirow[t]{2}{*}{ \# children living with mother } & 0.005 & 0.005 & $0.021^{* *}$ & -0.007 & -0.009 & $-0.011^{* * *}$ & $-0.011^{* * *}$ \\
\hline & $(0.007)$ & $(0.006)$ & $(0.010)$ & $(0.007)$ & $(0.006)$ & $(0.001)$ & $(0.001)$ \\
\hline \multirow[t]{2}{*}{ Parents living together } & -0.062 & -0.045 & -0.031 & $-0.055^{* * *}$ & $-0.043^{* *}$ & $-0.060^{* * *}$ & $-0.048^{* * *}$ \\
\hline & $(0.040)$ & $(0.036)$ & $(0.030)$ & $(0.018)$ & $(0.017)$ & $(0.005)$ & $(0.005)$ \\
\hline \multirow[t]{2}{*}{ Mother widowed } & -0.087 & -0.105 & -0.133 & $-0.083^{*}$ & $-0.075^{*}$ & $-0.068^{* * *}$ & $-0.062^{* * *}$ \\
\hline & $(0.078)$ & $(0.072)$ & $(0.081)$ & $(0.045)$ & $(0.041)$ & $(0.015)$ & $(0.014)$ \\
\hline \multirow[t]{2}{*}{ Log Father's income } & -0.004 & -0.006 & -0.004 & -0.002 & -0.001 & $-0.002^{*}$ & -0.001 \\
\hline & $(0.011)$ & $(0.010)$ & $(0.008)$ & $(0.004)$ & $(0.004)$ & $(0.001)$ & $(0.001)$ \\
\hline \multirow[t]{2}{*}{ Log Mother's income } & 0.008 & 0.006 & 0.005 & $0.014^{*}$ & 0.012 & $0.006^{* * *}$ & $0.006^{* * *}$ \\
\hline & $(0.019)$ & $(0.017)$ & $(0.018)$ & $(0.008)$ & $(0.008)$ & $(0.002)$ & $(0.002)$ \\
\hline Mother on welfare benefit & 0.018 & 0.011 & 0.028 & -0.006 & -0.006 & $0.025^{* * *}$ & $0.018^{* * *}$ \\
\hline & $(0.037)$ & $(0.033)$ & $(0.033)$ & $(0.023)$ & $(0.022)$ & $(0.008)$ & $(0.007)$ \\
\hline Mother on other benefit & 0.020 & 0.028 & 0.033 & $0.060^{*}$ & $0.050^{*}$ & 0.012 & 0.009 \\
\hline & $(0.051)$ & $(0.045)$ & $(0.065)$ & $(0.032)$ & $(0.029)$ & $(0.010)$ & $(0.009)$ \\
\hline Mother Housewife & -0.001 & -0.008 & 0.008 & 0.079 & 0.075 & $0.039^{* * *}$ & $0.035^{* * *}$ \\
\hline & $(0.135)$ & $(0.121)$ & (0.134) & $(0.060)$ & $(0.057)$ & $(0.013)$ & $(0.011)$ \\
\hline
\end{tabular}


Table 4 Estimates of the conditional probability of completing a degree by ethnic group (Continued)

\begin{tabular}{|c|c|c|c|c|c|c|c|}
\hline \multirow[t]{2}{*}{ Mother not present } & -0.151 & -0.148 & 0.090 & -0.036 & -0.030 & 0.009 & 0.007 \\
\hline & $(0.153)$ & $(0.138)$ & $(0.135)$ & $(0.066)$ & $(0.063)$ & $(0.016)$ & $(0.015)$ \\
\hline \multirow[t]{2}{*}{ Father on welfare benefit } & 0.009 & -0.009 & 0.044 & $0.044^{*}$ & 0.029 & $0.013^{* *}$ & 0.005 \\
\hline & $(0.029)$ & $(0.025)$ & $(0.038)$ & $(0.025)$ & $(0.023)$ & $(0.007)$ & $(0.006)$ \\
\hline \multirow[t]{2}{*}{ Father on other benefit } & $-0.083^{* *}$ & $-0.101^{* * *}$ & -0.026 & -0.000 & -0.001 & $0.019^{* * *}$ & $0.019^{* * *}$ \\
\hline & $(0.035)$ & $(0.032)$ & $(0.050)$ & $(0.022)$ & $(0.020)$ & $(0.006)$ & $(0.006)$ \\
\hline \multirow[t]{2}{*}{ Father not present } & -0.014 & -0.037 & -0.001 & 0.011 & 0.014 & -0.010 & -0.004 \\
\hline & $(0.102)$ & $(0.089)$ & $(0.073)$ & $(0.041)$ & $(0.038)$ & $(0.014)$ & $(0.012)$ \\
\hline \multirow[t]{2}{*}{ Constant } & $4.737^{* * *}$ & $4.685^{* * *}$ & $4.877^{* * *}$ & $4.530^{* * *}$ & $4.526^{* * *}$ & $4.790^{* * *}$ & $4.803^{* * *}$ \\
\hline & $(0.243)$ & $(0.217)$ & $(0.197)$ & $(0.116)$ & $(0.111)$ & $(0.028)$ & $(0.026)$ \\
\hline \multirow[t]{2}{*}{$\operatorname{Ln} \sigma$} & $-0.908^{* * *}$ & $-1.288^{* * *}$ & $-0.764^{* * *}$ & $-0.801^{* * *}$ & $-1.181^{* * *}$ & $-0.977^{* * *}$ & $-1.361^{* * *}$ \\
\hline & $(0.036)$ & $(0.087)$ & $(0.027)$ & $(0.014)$ & $(0.035)$ & $(0.004)$ & $(0.008)$ \\
\hline \multirow[t]{2}{*}{ K } & $-2.564^{* * *}$ & $-1.024^{* * *}$ & $-2.087^{* * *}$ & $-1.520^{* * *}$ & $-0.565^{* * *}$ & $-1.476^{* * *}$ & $-0.587^{* * *}$ \\
\hline & $(0.141)$ & $(0.179)$ & $(0.103)$ & $(0.049)$ & $(0.063)$ & $(0.011)$ & $(0.014)$ \\
\hline \multirow[t]{2}{*}{$\sigma$} & $0.403^{* * *}$ & $0.276^{* * *}$ & 0.466 & $0.449^{* * *}$ & $0.307^{* * *}$ & $0.376^{* * *}$ & $0.256^{* * *}$ \\
\hline & $(0.015)$ & $(0.024)$ & $(0.012)$ & $(0.006)$ & $(0.011)$ & $(0.001)$ & $(0.002)$ \\
\hline \multirow[t]{2}{*}{$\operatorname{Ln} \theta$} & & $1.336^{* * *}$ & & & $0.798^{* * *}$ & & $0.648^{* * *}$ \\
\hline & & $(0.305)$ & & & $(0.130)$ & & $(0.032)$ \\
\hline \multirow[t]{2}{*}{$\theta$} & & $3.805^{* * *}$ & & & $2.222^{* * *}$ & & $1.911^{* * *}$ \\
\hline & & $(1.160)$ & & & $(0.289)$ & & $(0.061)$ \\
\hline Log (pseudo) likelihood & -1266.94 & -1231.37 & -1889.83 & -4415.87 & -4284.20 & -42998.62 & -40590.70 \\
\hline Wald $X^{2}$ & 165.19 & 181.42 & 261.10 & 609.49 & 681.93 & 9891.41 & 11533.65 \\
\hline N & 1660 & & 2431 & 5902 & & 65418 & \\
\hline
\end{tabular}

* $p<.1$; ** $p<.05 ;$ *** $p<.01$.

Standard errors are in parentheses and adjusted for the clustering of students in institutions.

The results from parametric hazard models with and without unobserved heterogeneity component: the coefficients are given in accelerated failure time metric.

This paper provides novel evidence on ethnic differences in the performance in the higher education. The analysis reveals that all ethnic minority groups have a significantly lower hazard of completing a degree compared with Dutch students. Accounting for unobserved heterogeneity reduces ethnic disparities slightly but significant low degree performance remains robust to alternative specifications and methods. The disparity is the largest for students originating from non-western countries. In particular, Mediterranean and Caribbean students are less likely to finish their course of study in the period of ten years which is the time period of this study. There is no evidence that these ethnic disadvantages are a result of preliminary qualifications, the choice of subject and study type, or of a low socio-economic position of immigrant parents. Our results confirm the relatively high performance level of female students in higher education, which also holds for ethnic minority women.

However, the presence of ethnic disparity also for western students and little variance of the disparity across Mediterranean, Caribbean and other non-western students suggest that the ethnic disadvantage has little to do with the particular ethnic background of students. Students from the origin groups Mediterranean, Caribbean and other nonwestern, face a similar level of disadvantage in degree performance although Caribbean students are in a less disadvantaged position regarding their relatively small cultural 
and linguistic distance from the Dutch society. At the other extreme, Mediterranean students who belong to one of the most disadvantaged communities in the Netherlands regarding level of social, cultural and human capital seem not to experience additional disadvantages. Even western students have some significant deficit in degree performance compared to Dutch students although the socioeconomic position of western migrants does not significantly differ from the Dutch. The estimated performance of Mediterranean students, which is relatively better than expected among ethnic minority groups might come from two sources; first, Mediterranean students may be a selective group of more able individuals in their own community. A test of intuition was beyond this study because we have data of enrolled students only, not the potential population of students. Second, socioeconomic, cultural and linguistic differences between ethnic groups and Dutch society may play little role in the higher education system, compared to lower segments of the Dutch education system, given strong similarities in the performance of Mediterranean and Caribbean students, that are different groups in the sense of cultural and linguistic background. It is more likely that immigrant status plays a more dominant role in explaining ethnic disparities, rather than factors associated with a particular ethnic group such as immigration history and cultural and linguistic distances from the host country etc. It is also likely that non-western students should deal with institutionalized forms of dominant culture in the Dutch higher education system that serves as an implicit device to reduce performance in higher education. This outcome challenges the intuition that degree performance of students might be rank-ordered according to socioeconomic position of ethnic minority groups, to which students belong. Policy measures aiming to improve the degree performance of ethnic minorities need to be designed to cope with problems that affect all non-western immigrant groups similarly, rather than directing attention at a certain ethnic group. More effective policies may be sought in the sphere of bridging the social and cultural gap between non-western students and the dominant culture.

\section{Endnotes}

${ }^{1}$ Our exercises with separate groups strongly support this categorization of ethnic minority groups.

${ }^{2}$ In addition, in a separate regression model (not presented here) we also directly control for $\mathrm{HBO}$ and $\mathrm{WO}$ institutions to account for any effect of institutional differences on the performance. The result of this exercise is very similar for the models presented here.

Competing interests

The IZA Journal of Migration is committed to the IZA Guiding Principles of Research Integrity. The author declares that he has observed these principles.

\section{Acknowledgments}

The paper is part of a joint project with Statistics Netherlands; I am grateful to Kasper van der Heide and the Department of Total Statistics for allowing me the use of the Social-Statistical Database and CRIHO. I also thank to the anonymous referee of this journal for the comments.

Responsible Editor: Amelie Constant

Received: 10 July 2012 Accepted: 4 March 2013

Published: 5 April 2013

References

Arbona C, Nora A (2007) The influence of academic and environmental factors on Hispanic college degree attainment. Rev High Educ 30(3):247-269 
Bijl RV, Zorlu A, Van Rijn AS, Jennissen RPW, Blom M (2005) The Integration Monitor 2005. The social integration of migrants monitored over time: trend and cohort analyses., WODC Report. http://wodc.nl/onderzoeksdatabase/ integratiekaart-monitoring-integratie.aspx? $c p=44 \& \mathrm{cs}=6799$

Bourdieu P (1986) The Forms of Capital. In: Richardson JG (ed) Handbook for Theory and Research for the Sociology of Education., pp 241-258

Cameron SV, Heckman JJ (2001) The Dynamics of Educational Attainment For Black, White and Hispanic Males. J Political Econ 109(3):455-499

Chiswick BR, DebBurman N (2004) Educational attainment: analysis by immigrant generation. Econ Educ Rev 23:361_379

Colding B (2006) A dynamic analysis of educational progression of children of immigrants. Labour Econ 13(4):479-492

Colding B, Husted L, Hummelgaard H (2009) Educational Progression of Second-Generation Immigrants and Immigrant Children. Econ Educ Rev 28(4):434-443

Coleman JS (1988) Social capital in the creation of human capital. Am J Sociol 94:95-120, Supplement

Gang IN, Zimmermann KL (2000) Is child like parent? Educational attainment and ethnic origin. J Human Resour $X X X V: 550-569$

Gutierrez RG (2002) Parametric frailty and shared frailty survival models. Stata J 2(1):22-44

Herman G, Van De W, Frank Van T (2007) Ethnicity, Merit and Schooling in the Netherlands. Ethnicities 7(3):416-444

Hougaard P (1995) Frailty models for survival data. Lifetime Data Anal 1:255-273

Kalmijn M, Kraaykamp G (2003) Dropout and Downward Mobility in the Educational Career: An Event-History Analysis of Ethnic Schooling Differences in the Netherlands. Educ Res Eval 9:265-289

Kao G, Thompson JS (2003) Racial and ethnic stratification in educational achievement and attainment. Annu Rev Sociology 29:417-442

Lambert P, Collett D, Kimber A, Johnson R (2004) Parametric accelerated failure time models with random effects and an application to kidney transplant survival. Stat Med 23(20):3177-3192

Leslie D (2005) Why people from the UK's minority ethnic communities achieve weaker degree results than whites. Appl Econ 37(6):619-632

Light A, Strayer W (2000) The determinants of college completion: school quality or student ability? J Hum Resour 35:299-332

Museus SD, Quaye SJ (1999) Toward an intercultural perspective of racial and ethnic minority college student persistence. Rev High Educ 33(1):67-94

Nielsen HS, Rosholm M, Smith N, Husted L (2003) The school-to-work transition of 2nd generation immigrants in Denmark. J Popul Econ 16:755-786

Nora A, Cabrera AF (1996) The role of perceptions of prejudice and discrimination on the adjustment of minority students to college. J High Educ 67(2):119-148

Rijken S, Maas I, Ganzeboom HBG (2007) The Netherlands: Access to higher education - Institutional arrangements and inequality of opportunity. In: Grusky DB, England P (eds) Stratification in higher education. A Compartive study. Standford University Press, Standford, California

Riphahn RT (2003) Cohort effects in the educational attainment of second generation immigrants in Germany: An analysis of census data. J Popul Econ 16:711-737

Schnepf SV (2007) Immigrants' educational disadvantage: an examination across ten countries and three surveys. J Popul Econ 20(3):527-545

Stanton-Salazar RD (1997) A social capital framework for understanding the socialization of racial minority children and youths. Harvard Educ Rev 67(1):1-40

Strayhorn TL (2010) When race and gender collide: social and cultural capital's influence on the academic achievement of African American and Latino males. Rev High Educ 33(3):307-332

van Ours J, Veenman J (2003) The educational attainment of second-generation immigrants in The Netherlands. J Popul Econ 16(4):739-754

Warikoo N, Carter P (2009) Cultural explanations for racial and ethnic stratification in academic achievement: a call for a new and improved theory. Rev Educ Res 79(1):366-394

Zorlu A, Hartog J (2012) Employment assimilation of immigrants in the Netherlands: dip and catchup by source country. International Journal of Population Research 2012(2012):23. doi:10.1155/2012/634276, Article ID 634276

doi:10.1186/2193-9039-2-3

Cite this article as: Zorlu: Ethnic disparities in higher education. IZA Journal of Migration 2013 2:3.

\section{Submit your manuscript to a SpringerOpen ${ }^{\circ}$ journal and benefit from:}

- Convenient online submission

- Rigorous peer review

- Immediate publication on acceptance

- Open access: articles freely available online

- High visibility within the field

- Retaining the copyright to your article

Submit your next manuscript at $\gg$ springeropen.com 